\title{
'Unwholesome Reversions': Contagion as Dramaturgy in The Dutch Courtesan
}

Karen Britland argues that The Dutch Courtesan uses contagion not only in its literal invocation of disease but also as a conceptual framework. The proximity of episodes invites an audience to read across plots so that seemingly separate threads become metaphorically cross-contaminated, providing tacit counter-narratives and refutations. This paper examines some of the conceptual contaminations presented by the play, moving from its consideration of venereal disease and human migration to the ways in which the emotional pain inflicted on its more liminal characters - Beatrice and Mulligrub - can be read as contaminating the positive narratives put forth by Freevill and Cocledemoy.

The Dutch Courtesan is a play abundantly concerned with movement and circulation: of people, of goods, of ideas, and of diseases. As an early example of city comedy, the play ties its many forms of restless motion to the excitement and anxiety of life in a city as circulation and proximity generate an energy that is simultaneously thrilling and threatening. Karen Britland argues that the play's concern with disease and contagion links to its depiction of urban life in which freedom of movement (primarily for men) opens up opportunities for dalliance while also creating risks of infection. ${ }^{1}$ Britland pushes the notion further, expanding the idea of contagion beyond the play's themes to its conceptual framework, by arguing that the proximity of tropes or events invites an audience to analyze them relationally so that ideas or images from one scene cross over and metaphorically infect another scene or plot. Thus, Britland argues, Freevill's musical wooing of Beatrice in 2.1, as a self-contained episode, is a sincere and conventional romantic moment, but its proximity to the combination of music, sexuality, and commodification in the preceding scene with Freevill and Franceschina tacitly critiques, or

Noam Lior (noam.lior@utoronto.ca), director of the 2019 Dutch Courtesan, is a cofounder and production dramaturge for Shakespeare at Play (www.shakespeareatplay. ca) and completed his PhD at the University of Toronto's Centre for Drama, Theatre and Performance Studies. 
at least complicates, the trope. While the characters do not explicitly acknowledge the linking of these ideas, nevertheless the result is that romance is 'contaminated' by its proximity to 'grubby selfishness and hypocrisy'. ${ }^{2}$ Such 'contamination' is a function of spectator or reader attention that treats the play like a pointillist painting, assembling an overall picture by combining its individual particles into larger patterns. Through this process of construction and the possibility that the individual particles will cross-contaminate in the spectator's imagination, Britland can claim that the play's 'portrait of city life ... on the one hand, seems to endorse xenophobic violence and yet, on the other, gives its audience the tools to examine and reject such knee-jerk reactions. ${ }^{3}$

'Contamination' and its analogues are loaded terms, emphasizing the negative aspect of what is surely a two-way exchange. The sincere romance of the Crispinella/Tisefew plot, for example, can inject some positivity or sweetness into Franceschina's storyline. My focus here is on that negative aspect, however, as it provides a useful rebuttal to some of the more toxic aspects of the play. The Dutch Courtesan contains numerous instances of zero-sum games, in which not only does one character's or group's prosperity come at the expense of others, but also that expense is elided or ignored in order to present the particular game - or model of circulation - as positive and beneficial. This article examines instances in which The Dutch Courtesan introduces seemingly positive models of circulation or exchange then offers proximate examples that refute or complicate these models by presenting their hidden costs or consequences, conceptually 'contaminating' the former with the latter in the audience's imagination. I begin with some more visible examples of this strategy, considering the play's concern with literal contagion followed by the less overt treatment of international relations and migration. I then consider some less obvious versions of conceptual contagion in what might be termed the play's emotional economies, positing emotional suffering - of Beatrice and Mulligrub in particular - as an element that can contaminate and contest the tidy moral arguments offered by the play's presumptive protagonists Freevill and Cocledemoy. My treatment of these emotional economies includes the possibilities of performance, drawing on the Toronto production from March 2019. Performance choices that highlight the emotional suffering of the play's more liminal characters offer the opportunity for a modern critical interpretation that probably contradicts or exceeds the play's original intentions but creates alternative resonances for a modern audience.

In the play's first scene, Freevill, the ostensible leading man, makes an analogy linking the political with the personal, connecting international affairs with extramarital affairs. His argument comes as part of Freevill's verbally dexterous 
defence of brothels and prostitution, in a debate with his morally upright companion Malheureux. When Malheureux demands the reason for this position, Freevill elaborates: 'Marry, lest my house should be made one. I would have married men love the stews, as Englishmen love the Low Countries, wish war should be maintained there, lest it should come home to their own doors' (1.1.52-4). This analogy, spanning from England's relationship with the Netherlands to husbands' relationship with brothels via London's relationship with the suburbs, offers stable models of circulation in which movement of funds, of forces, and of individuals is controlled, its meaning fixed and final. This comparison, appropriately, comprises many moving parts, and it deserves some detailed examination as it touches on several of the play's concerns as well as some of its modern resonances. The core analogy compares foreign policy with domestic life, figuring fornication or seduction as equivalent to war. The deleterious effects of war are death and destruction of property, while unregulated sexual appetite (in Freevill's limited perspective) risks cuckoldry. Englishmen 'love' the Low Countries by supporting the Protestant Netherlands' wars against Catholic Spain. The English avoid having the conflict arrive at their own shores by providing financial support and limited military assistance to the Dutch. In Freevill's example, then, English support keeps the conflict both contained and distant, and its single significant consequence is the relative safety of England. That is to say, the war still presumably causes death and destruction, but those costs get deferred and displaced onto others, to England's benefit. Similarly, on the other side of Freevill's analogy, brothels draw strife away from respectable homes, giving a release to libidinous energies that would otherwise threaten domestic harmony. At this point, the terms become ambiguous as the argument does not explain precisely how the availability of brothels would provide married men with peace of mind. The most likely possibility is the threat of cuckoldry: brothels provide an outlet for young men's affections, keeping them from seducing married women and so enabling husbands to relax. Thus, in Freevill's imagined future of marital comfort, his security as a husband - a role that frequently includes anxiety about cuckoldry, as his father Lionel Freevill demonstrates later in the play (4.4.20) - will increase because the brothels will attract libidinous young men and give them a place to release their sexual desires away from honest wives. ${ }^{5}$ Curiously — or appropriately, depending on how one reads Freevill — this interpretation largely ignores the possibility of wives having any sexual agency, or at least that such agency might lead them out of the home or toward brothels. The argument also conveniently ignores the fact that Freevill is in that very moment a bachelor on his way to a brothel, implying that the need driving Freevill to the brothel as a bachelor will vanish once he 
becomes a husband. Regardless of the specifics, Freevill imagines 'the stews' as equivalent to 'the Low Countries': a distant horizon that draws off and contains conflict, leaving the home front untroubled. The resulting model circumscribes and controls circulation in a structure that is not only stable but also perpetually advantageous to England, to married men, and to Freevill himself.

While no one directly confronts Freevill with a counter-argument to his tidy fantasy, its proximity to other characters' perspectives prompts an indirect resistance. Crispinella, sister to Freevill's fiancée Beatrice, articulates a link between the stews and upstanding citizens' homes, the connection being literal contagion. Expostulating on gender inequality, specifically as it applies to marriage, Crispinella describes a series of hypothetical circumstances, all based on the central claim that, in marriage as in society at large, women 'must' while men 'may' (4.1.2935). That is, social norms offer men a variety of freedoms while presenting women with binding strictures. Crispinella's list crescendos with the assertion that 'if [the husband is] a loose liver, we [wives] must live upon unwholesome reversions' (32). Curiously, editions of The Dutch Courtesan tend not to gloss 'loose liver', meaning one who lives loosely, presumably by sleeping with prostitutes and/or having extra-marital affairs. 'Unwholesome reversions' thus refers to venereal diseases contracted by the husband and transmitted to the wife, who would, in David Crane's phrasing, "'inherit" from [her] husband the pox he has acquired from a whore. ${ }^{6}$ In Crispinella's formulation of gender roles, wives are proscribed from enjoying extra-marital relations in the way that husbands can but are nevertheless subject to the consequences of those affairs. Britland points out that 'Reversion was a legal term, connoting the return of an estate to its original owner, or to that owner's heirs', a gloss that transforms sexually-transmitted infection into a kind of legal-biological-moral inheritance that wives derive from their husbands' philandering. Adding insult to injury, as Crispinella argues, men find sexual excitement in 'things got with fear and hoped with pleasure', in the thrill of affairs outside marriage, whereas 'duty stales and flats their appetite' (34-5). Married sex, lacking in the challenge and uncertainty of affairs, is thus dull and unappetizing, potentially to the point of causing impotence. ${ }^{7}$ Contrary to Freevill's implication that marriage would contain his desire to frequent brothels, Crispinella argues that marriage and its attendant obligatory sex is precisely what drives men from the home to seek out sex elsewhere. ${ }^{8}$ Whereas Freevill's formulation posits a stable system in which the movement of men from the city to the stews is unidirectional and beneficial, Crispinella reimagines the dynamic as subject to multiple corruptions, its consequences spreading by contagion to affect - and infect — both husband and wife. 
As Meghan C. Andrews points out in her essay in this issue, Marston concretizes this uncontrolled movement through a prop. Beatrice's ring, which initially serves to mark her engagement to Freevill, changes hands repeatedly. The ring is given by Freevill to Malheureux as evidence for their concocted murder plot, then by Malheureux to Franceschina (indirectly, by way of the bawd Mary Faugh); Franceschina gives the ring to Freevill (at this point disguised as the French pander Don Dubon) with instructions to use it to taunt Beatrice with Freevill's infidelity. The ring thus begins as a conventional signifier of faith and monogamy but goes through multiple instances of corruption-through-contact, accumulating a variety of significations: romance, sex, friendship, contagion, commerce, betrayal, suffering. Beatrice's ring is one of two in the play, both of which get carefully tracked for some time only to disappear in the later scenes. ${ }^{9}$ Compared to her earlier observations, which include descriptions of gallants' 'goose-turd-green teeth' (3.1.21) and the exclamation (or punchline) that, rather than kiss such gallants, Crispinella 'had as lief they would break wind in [her] lips' (24-5), her later talk of 'loose livers' and 'unwholesome reversions' is more genteelly poetic. The phrasing is sonorous, oblique, and further distanced from modern idiom, making it far more challenging for a modern actor to communicate the incisive invective of these key concepts to a modern audience. Brianna Maloney, our production's Crispinella, routinely conjured sympathetic laughter from audiences with much of Crispinella's material, which easily plays as a sharply-observed stand-up comedy routine. On this line, and the language of 'unwholesome reversions' and 'loose livers' however, Marston's idiom proved to be a solid barrier between early modern context and modern playgoers.

Where Crispinella's analysis provides a textual refutation of the domestic portion of Freevill's analogy, the play provides a contextual refutation to the international portion in the form of its title character. While the play's dialogue never overtly addresses Anglo-Dutch collaboration against Spain, the play's eponymous Dutch courtesan, Franceschina, emblematizes the influx of Dutch migrants and refugees entering London precisely because of the conflict Freevill describes. ${ }^{10}$ Marjorie Rubright explores at length the ways in which the increased presence and visibility of Dutch immigrants in London links to the rise of Dutch characters on the early modern English stage. ${ }^{11}$ The movement of migrants into - and through - London is a preoccupation of the play and is the logical result of the conflict that Freevill endorses, though neither Freevill nor Marston explicitly acknowledges the causal link. Though the argument here is far subtler than the very explicit connection that Crispinella makes, Franceschina - and, to a lesser extent, the Mulligrubs - represents part of the human cost of the arrangement 
that Freevill praises, the unpleasant and largely unacknowledged consequence of conflict. Considered in this light, Franceschina is a foreign refugee sex worker rendered as an 'other' in the play due to the intersection of her gender, her social position, and her accent. Similarly, the Mulligrubs, the corrupt tavern-keepers of the play's subplot, are members of the Family of Love, a Protestant sect that traces its origins to the Netherlands. ${ }^{12}$ The Mulligrubs' status as religious outsiders makes them suspect within the play's rendition of London society. Over the course of the play, Franceschina's multiply-outsider status marks her as precarious and enables Freevill (and later Malheureux) to displace onto her the blame for a variety of social ills; Mulligrub occupies a similar position of precarity, though on an inverse path. At the play's conclusion, Franceschina is ostracized, led off by officers 'to the extremest whip, and jail' (5.3.53) for soliciting Freevill's murder. Mulligrub, in a parallel trajectory, suffers a variety of private and public humiliations before reintegrating into the play's community, albeit with his outsider status still intact. At the play's conclusion though he escapes the noose Mulligrub seems just as likely to suffer the jests of Freevill and company, or the capricious cruelties of Cocledemoy, and has no greater recourse to civic justice than he did at the play's outset.

In this sense, the presence of Franceschina and the Mulligrubs in London acts as a kind of metaphorical contamination in that it collapses the conceptual distance between England and the Netherlands set up in Freevill's model of circulation. This model in which Freevill exults, then, not only produces urban types such as Franceschina and the Mulligrubs but also marks them as other, maintaining them in a precarious position within the city, a situation that works to Freevill's advantage (mostly), but which the audience can read more critically.

I want to be careful here because the unintended consequence of paralleling these two aspects of Freevill's analogy in this way is that the comparison figures migrants and refugees as analogous to disease in a manner that echoes the rhetoric of anti-immigrant demagogues from the early modern period to the present day. I certainly neither intend nor support such an argument, nor is it my contention that Marston (or, indeed, Freevill) offers such a comparison tacitly or explicitly. The play registers a variety of anxieties about migration and immigration, but they are more nuanced and less insidious than this emergent rhetoric might suggest. While the play does sometimes deploy its characters in ways that suggest metaphorical contagion, it in no way limits this tendency to its foreigners. Britland examines ways in which the play's dramaturgy 'foregrounds London's permeability' by having characters constantly irrupting into spaces that seem private or safe. ${ }^{13}$ While Franceschina and the Mulligrubs move in this manner occasionally, 
by far the worst offenders are Freevill and Cocledemoy, both of whom infect the play's many locations, virus-like, changing appearance, behaviour, and costume as necessary.

I would argue that Freevill and Cocledemoy can and should be read as agents of contamination in this play, though they both argue for the rightness of their respective causes. In this instance, the conceptual contagion that infects Freevill and Cocledemoy's claims to innocence relies on what we might call the play's emotional economies. Freevill and Cocledemoy both claim a virtuous or at least innocent action, but the suffering of other characters, which performance can elide or emphasize, resists this claim. Freevill's plan, the motivating action of the play's main plot, consists of an attempt to stabilize his own situation while avoiding its unpleasant consequences. Prior to the play's first scene, Freevill has been courting the respectable Beatrice while also regularly seeing (and presumably sleeping with) Franceschina. In the play's early scenes, Freevill schemes to free himself of Franceschina by introducing her to the innocent Malheureux, thus enabling him to pursue Beatrice unencumbered (though possibly already infected with 'unwholesome reversions'). As is typical for city comedies, the plan encounters a series of complications so that the relatively simple intended chicanery rapidly devolves into deceptions, disguises, and faked deaths with potentially lethal results for multiple characters. A number of threads are worth following here: Britland discusses Freevill's effort to place the consequences for his machinations onto Franceschina, an effort that may be unconvincing for the audience, but which is successful within the play as Franceschina is removed to imprisonment and 'extremest' whipping. ${ }^{14}$ Freevill's treatment of Malheureux is similarly troubling, as the latter is brought to the gallows and made to believe that he is about to be executed for Freevill's supposed murder. The ostensible motive for this plot thread is a kind of shock treatment: Freevill explains to the audience that this near-death experience is meant to cure Malheureux of his fixation on Franceschina, and Malheureux explicitly forgives and thanks Freevill for this treatment, though his sincerity in that moment is open to question and can certainly be modulated in performance.

I wish to focus, however, on the consequences for Beatrice, whose fiancé abandons her almost immediately after their engagement; she then becomes convinced that he has died while also learning of his affair with Franceschina. Beatrice's suffering is difficult to calibrate, both on the page and on the stage. Apropos of her name, the character is loving, innocent, and patient to the point of absurdity. Beatrice's response when hearing of Freevill's death and betrayal is pity, piety, and prayer. In one of the play's most darkly comic moments, Beatrice commits 
to loving Franceschina in Freevill's memory, much to Franceschina's chagrin (4.4.60). Overcome with emotion, Beatrice swoons and is carried in. The next time she appears, in 5.2, Beatrice is alone with Crispinella (onstage without their nurse for the only time in the play) and contemplating suicide, desolate at the thought of living in a world without either a living Freevill or a pure memory of his love. This moment of desolation and support is brief as Nurse Putifer interrupts the sisters' intimacy as does Freevill, still disguised as Don Dubon. Freevill continues his charade, offering to sing to Beatrice 'to make sweet [her] grief',15 and his music causes Beatrice to swoon a second time, whereupon Freevill removes his disguise, though he resumes it shortly in order to defer full discovery until the final scene $(5.2 .32,36-44)$.

Between these two moments of Beatrice's suffering, at the end of 5.1 Freevill stands alone on stage and soliloquizes on Beatrice's suffering (5.1.110-17). In contrast to the 'tearless woman' Franceschina, Beatrice weeps, showing an outward sign of inward goodness, virtue, and love. Like Tom Sawyer, Freevill lives to hear himself eulogized, which moves him to something like sincere appreciation, a recognition of depth of feeling if not necessarily reciprocation of it. This response is the closest that Freevill approaches to a moment of remorse and self-awareness, though lacking a great deal of depth. The trope of using women characters' suffering in order to support or produce male characters' motivation and interiority is depressingly familiar, though of course its resonance has changed over time. ${ }^{16}$ Even if we accept Freevill's conversion as sincere, its examination is limited to reflecting on a choice between two kinds of women, and Freevill's claim to character growth roots itself in his assertion that wise men ought to choose the propriety of marriage represented by Beatrice rather than the hellish embrace of prostitution figured by Franceschina. In terms of an audience's interpretation, much here depends on how the actor - in collaboration with the director, dramaturge, costume designer, et al - presents Beatrice in the two bracketing scenes. Beatrice's commitment to loving Freevill and to cherishing his memory can easily be played up for laughs, reading as melodramatic, default positions of a one-note character rather than expressions of a sincere interiority. If Beatrice's reactions are slower, however, and invite an audience to see them as intentional and genuine, then they can work to undermine Freevill's supposed transformation. If Beatrice's suffering registers for an audience, then we see Freevill cause her intense pain and explicitly recognize that fact before immediately going back to cause more pain. The apology that follows is at best disingenuous, at worst perjured: Freevill praises Beatrice as 'the admired glory of [her] sex', denies that his love was ever 'false to [her]', and excuses his manipulations by claiming he only 'presumed to 
try [her] faith too much' (5.2.60-2). In response to Crispinella's accusation of ill behaviour, Freevill equivocates and obfuscates, offering vague promises for later explanations that will turn present frowns into amusement. What has changed here is the object of Freevill's devotion, rather than his behaviour. While Freevill's shift from Franceschina to Beatrice can be read as a sincere conversion, the difference is entirely in whom he loves, rather than how he loves. At the play's conclusion as at its outset, Freevill's notion of 'love' remains bound up in deferred harm, in finding situations that are beneficial to him at others' expense.

Beatrice is innocent but not naïve. When she first appears in 2.1, she immediately expresses her inability to address Freevill in the manner of a courtesan, with 'a mistress' compliment, / Forced discourses, or nice art of wit' (2.1.11-12). Instead, Beatrice says, she can offer a set of negative virtues: 'Unsullen silence, unaffected modesty, / Unignorant shamefastness' (15-16). Unlike Mistress Mulligrub, who manages, at best, an ignorant shamefastness, Beatrice does not lack self-awareness. 'Unignorant shamefastness' suggests that her innocence is an active choice rather than a default state. She understands that there are other kinds of women in the world, that Freevill may associate with them, and that her own charms may pale in comparison. Beatrice articulates her faith in Freevill and her own vulnerability because of that faith, entreating him not to wrong her (19-23). At their next meeting, Beatrice reiterates this request twice in short succession, beseeching Freevill to 'be not tyrannous' and to 'wrong [her] not' (3.1.220-2). She again describes herself in contrast to an absent other: 'faith, my love's not lust' (221). Her innocence still represents a lack of skill, but she reconfigures it as an intentional resistance to a corrupted world. Beatrice repeatedly expresses her faith and trust in Freevill and repeatedly entreats him not to betray that trust, all of which makes Freevill's subsequent and near-immediate betrayal that much more pointed. His disregard for Beatrice's well-being amidst his praise for her virtue shocks not as intentional cruelty but rather as brutal negligence.

Freevill's treatment of Malheureux becomes a potential cross-contaminant to his treatment of Beatrice. Through a sequence of disguises and deceptions, Freevill causes both Malheureux and Beatrice to suffer emotionally and to prepare for and accept death, in Beatrice's case through a contemplation of suicide, in Malheureux's through the threat of hanging. The goal in Malheureux's case is to purge him of a love both excessive and attached to an unsuitable target. In this respect, Malheureux's love for Franceschina is eerily similar to Beatrice's love for Freevill, and an audience might reasonably hope that they both find a cure. Beatrice's last line in the play strongly suggests that that her attachment to Freevill is intact, though the moment is ambiguous. After Freevill discovers himself, he assumes 
his disguise again for Tisefew's entrance (5.2.77). Slightly later, as the company prepares to make its way to see the impending double execution, Beatrice invites Freevill — still in his disguise as the pander Don Dubon — to attend them and to 'be [their] guide' (133). Freevill responds, 'I am your servant', prompting Tisefew to sarcastically suggest that Beatrice make Freevill/Don Dubon her 'love', a suggestion to which Beatrice enthusiastically and cheekily agrees (134-7). Tisefew's shocked 'Sdeath o' virtue!' (138) suggests that some action takes place here. The Toronto production had Beatrice spin Freevill into an embrace, and then dip him, an echo of their dance together in the masque of 4.1 but with her taking the role of active partner. This was a crowd-pleasing bit of business and provided both the actor and the character with a moment of agency, but also substantially let Freevill off the hook.

Where Freevill consistently defers the reckoning of his ethical and emotional debts, Cocledemoy insists that he has incurred no debt as he has caused no lasting harm. Here again, a focus on emotional suffering in performance contaminates Cocledemoy's argument. Over the course of the Mulligrub-Cocledemoy plot, Cocledemoy relieves his hapless victim of a succession of valuable objects, beginning with the theft of the goblets related in the play's opening scene, to the bag of cash in 2.3, the gold bowl in 3.3, and the salmon in 3.4. In addition to the material losses, Mulligrub also stands in danger of losing his dignity, his faith, his sanity, and — in the final scene — his wife and his life. The plot resolves with an exchange of forgiveness as Mulligrub - believing he is about to hang - pardons all who have wronged him (5.3.125-6). Cocledemoy, at this point disguised as a sergeant, presses Mulligrub to repeat this pardon before shedding his disguise to reveal his identity (135-40). Claiming that his actions were entirely 'for wit's sake', Cocledemoy proceeds to return all of Mulligrub's property, thus laying claim to his dubious status as 'honest Cocledemoy' (147-52). In the economic model that Cocledemoy suggests, his potentially-criminal actions are blameless because he has returned the goods to their owner, leaving Mulligrub financially unharmed. The counter-case, based on Mulligrub's emotional suffering, is more difficult than the case for Beatrice because Mulligrub is an overtly clownish, comic figure, his outsize bursts of choler far more exaggerated than her strained patience and credulity. Moreover, Mulligrub gets presented as a kind of social vice, a representative of a foreign-tinged religious minority and a self-avowed practitioner of unethical and illegal business practices. Even his confession before the noose is comically constructed, its terms suffering from either malapropism or intentional deception: 'If I owe any man anything, I do heartily forgive him' (103-5). If played with sincerity, however, Mulligrub's near-death 
conversion can be genuinely moving, a difficult setting aside of his former choler and an embrace of virtue through forgiveness. Unlike Freevill, Mulligrub recognizes his past behaviour: reminded by Cocledemoy of his previous threats against him, Mulligrub avows, 'That hard heart of mine has procured all this, but I forgive as I would be forgiven' (139-40). As the play ties up its few remaining loose ends, Cocledemoy shifts rapidly from defending his own behaviour to an epilogue defending the play more generally, enjoining the audience to applaud 'if with content our hurtless mirth has been' (175). Not only has he received forgiveness and returned the offending goods (with the exception of Malheureux's purse, pilfered before the gallows), but also his actions have served to entertain and are thus blameless. Cocledemoy's calculation has no place for Mulligrub's emotional suffering: in the play's pattern of zero-sum games, Cocledemoy's amusement and by extension, the audience's - has come at the expense of Mulligrub's fiscal, mental, and physical well-being, not to mention the health of his marriage.

The state of both Beatrice and Mulligrub at the play's conclusion is difficult to pin down. Beatrice remains on stage through much of 5.3, but speaks no lines in the scene, though she witnesses both averted executions and Crispinella's betrothal to Tisefew. The tidiness of the play's conclusion and the conventions of the comedy genre invite an audience to invest in the Freevill-Beatrice relationship, but Beatrice's silence, as well as Freevill's earlier treatment of her, leaves room for uneasiness, space for contaminating ideas to take hold. A production that calls attention to Beatrice's pain in earlier scenes makes it much more difficult for an audience to view their marriage with optimism, especially a modern audience who might already be more inclined to skepticism regarding Freevill's antics and Beatrice's long-suffering patience. In the plot's emotional development, Freevill is a perpetual bad debtor, forever promising that explanations, apologies, and amends will follow at a later date. Cocledemoy, meanwhile, offers present mirth and present laughter, insisting that there's no harm done as long as the goods have been returned and the audience had a good time. Both these arguments can be compelling as the characters proffering them can be dynamic and charming. While the play does not explicitly counter their arguments - Franceschina, the one character positioned to actively protest has already been carried forcibly off the stage - the pain that Freevill and Cocledemoy inflict upon Beatrice and Mulligrub respectively, in Britland's terms, 'gives [the] audience the tools to examine and reject ${ }^{\prime} 17$ their tidy conclusions. The consequences of their actions, though displaced onto others, contaminate and infect the professed innocence of their intentions. 


\section{Notes}

1 John Marston, The Dutch Courtesan, ed. Karen Britland (London, 2018), 7. All further references to the play are to this edition.

2 Ibid, 3.

3 Ibid, 1.

4 This term is Freevill's first use of the word 'love' in the play, and it seems ironic if not deeply cynical that the play's presumptive romantic lead uses 'love' here to describe approval for a practice from which he stands to benefit rather than any kind of emotional or even sexual devotion.

5 Jean Howard goes further, describing the brothel as a 'buffer zone' that contains 'sexual assaults', a reading that pushes Freevill's attitude toward sex toward the military violence of the other half of the analogy. Jean E. Howard, 'Mastering Difference in The Dutch Courtesan', Shakespeare Studies 24 (1996), 108.

6 John Marston, The Dutch Courtesan, ed. David Crane (London 1997), 4.1.35n, https://doi.org/10.5040/9781408162774.00000018.

7 Dutch Courtesan, ed. Britland, 191, 4.1.46n; The Dutch Courtesan, ed. Crane, 4.1.46n.

8 Oxford English Dictionary (OED), s.v. 'duty', n. 3c notes that by this time 'duty' meant not only a moral or religious obligation but also a financial one: 'a payment to the public revenue levied upon the import, export, manufacture, or sale of certain commodities'. In Crispinella's accusation, married men treat sex with their wives as the price paid for marriage. See Othello's Emilia, especially the social/sexual/financial/ national betrayal inherent in 'Say that [men] slack their duties / And pour our treasures into foreign laps' (William Shakespeare, Othello, ed. Tucker Brooke [New Haven, 1947], 4.3.88-9).

9 Beatrice's ring is last mentioned in 5.1 and does not reappear in dialogue or stage directions when Beatrice and Freevill reunite and reconcile in the following scene; the other ring, central to the Tisefew-Crispinella-Caqueter triangle, disappears after 3.1, though the Toronto production brought it back in 4.1 for Tisefew's proposal to Crispinella.

10 Marjorie Rubright, Doppelganger Dilemmas: Anglo-Dutch Relations in Early Modern English literature and Culture (Philadelphia, 2014), 39-42, https://doi. org/10.9783/9780812290066; Britland, Dutch Courtesan, 1.1.77n.

11 Rubright, Doppelganger Dilemmas, 42.

12 Dutch Courtesan, ed. Britland, 50-4.

13 Ibid, 54-5. 
14 Ibid, 3.

15 In the Toronto production, as in Michael Cordner's York production, the song here reprised the wooing song used in 2.1 .

16 The trope is now commonly known as 'fridging', thanks to Gail Simone's analysis of this phenomenon in comics. See "Women in Refrigerators", 1999, https://www.lby3. com/wirl.

17 Dutch Courtesan, ed. Britland, 1. 
